\title{
Malignant granular cell tumor of the ulnar nerve: A case report of long-term follow-up and literature review
}

\author{
Sei Morinaga ${ }^{1}$, Norio Yamamoto*1 ${ }^{*}$ Katsuhiro Hayashi ${ }^{1}$, Akihiko Takeuchi ${ }^{1}$, Shinji Miwa ${ }^{1}$, Kentaro Igarashi ${ }^{1}$, Hirotaka \\ Yonezawa ${ }^{1}$, Yohei Asano ${ }^{1}$, Shiro Saito ${ }^{1}$, Takayuki Nojima ${ }^{2}$, Hiroyuki Tsuchiya ${ }^{1}$ \\ ${ }^{1}$ Department of Orthopedic Surgery, Kanazawa University School of Medicine, Kanazawa, Japan \\ ${ }^{2}$ Department of Diagnostic Pathology, Kanazawa University, Kanazawa, Japan
}

Received: April 12, 2021

DOI: $10.5430 /$ crcp.v8n1p27
Accepted: August 9, 2021

Online Published: July 24, 2021

\begin{abstract}
Background: The incidence of malignant granular cell tumors, representing an extremely rare Schwann cell-derived tumors with a poor prognosis, is reported to be approximately $0.2 \%$ of all malignant soft tissue tumors. We report a case of a malignant granular cell tumor originating from the ulnar nerve.

Case presentation: A 71-year-old woman presented with a mass in her right forearm. Magnetic resonance imaging showed a tumor with homogenous intensity of T1 and heterogeneous hyperintensity of T2, continuous with the ulnar nerve. An incisional biopsy revealed a malignant granular cell tumor, and a marginal excision of the tumor was performed. Histologically, the tumor size was $9.2 \mathrm{~cm}$ and consisted of eosinophilic, granular polygonal to round and spindle-shaped cells, with vesicular and prominent nucleoli, and increased mitosis. Immunohistochemically, the tumor cells were positive for S-100 protein, CD68, H3K27me3, TFE3, and SOX10 and negative for smooth muscle alpha-actin, desmin, cytokeratin AE1/3, epithelial membrane antigen, and synaptophysin. The Ki-67 positivity rate was $12 \%$. These findings were consistent with those of other malignant granular cell tumors. In addition, no metastases or recurrence could be observed 15 years after the excision.

Conclusion: Surgical resection represents the standard treatment option, whereby in our case the diagnostic criteria for malignant granular cell tumors were histologically met. Patients with malignant granular cell tumors have a poor prognosis. However, no metastases or recurrence was observed in this case 15 years after surgery.
\end{abstract}

Key Words: Granular cell tumor, Long-term follow-up, Malignant, Ulnar nerve

\section{INTRODUCTION}

Granular cell tumors are rare and account for approximately $0.5 \%$ of all soft tissue tumors. ${ }^{[1]}$ Malignant granular cell tumors are soft tissue tumors derived from Schwann cells, with a frequency of occurrence reported to be approximately $0.2 \%$ of malignant soft tissue tumors and $2 \%$ of all granu- lar cell tumors, which is extremely rare and has metastatic capacity. ${ }^{[2,3]}$ The gold standard of treatment is surgical resection, as the tumor is resistant to chemotherapy and radiation therapy. ${ }^{[4,5]}$ To the best of our knowledge, 17 cases of malignant granular cell tumors arising from various peripheral nerves have been reported so far. ${ }^{[4,6-21]}$ We report a case of

*Correspondence: Norio Yamamoto; Email: norinori@med.kanazawa-u.ac.jp; Address: Department of Orthopaedic Surgery, Graduate School of Medical Sciences, Kanazawa University, 13-1 Takara-machi, Kanazawa, Ishikawa 920-8640, Japan 
a malignant granular cell tumor originating from the ulnar nerve with a good clinical outcome.

\section{Case presentation}

The patient was a 71-year-old woman who noticed swelling in her right forearm and numbness in her right 4th and 5th fingers in September 2003. As the swelling gradually progressed, she consulted a doctor in May 2004. She was referred to our department because a soft tissue tumor was identified on magnetic resonance imaging (MRI). The patient's medical history included appendicitis. The mass on the ulnar side of the right forearm was firm. There was numbness in her right 4th and 5th fingers of the ulnar nerve distribution, tenderness at the mass, and Tinel-like sign. There was no warmth or erythema, and the mass was immobile. Radiographs showed a swelling of the soft tissue on the ulnar side of the right forearm, whereby no calcifications were observed. MRI showed a tumor with homogenous intensity of $\mathrm{T} 1$ and heterogeneous hyperintensity of $\mathrm{T} 2$, continuous with the ulnar nerve. There was gradual enhancement of the mass on MRI with contrast and moderate accumulation on thallium scintigram(see Figure 1).
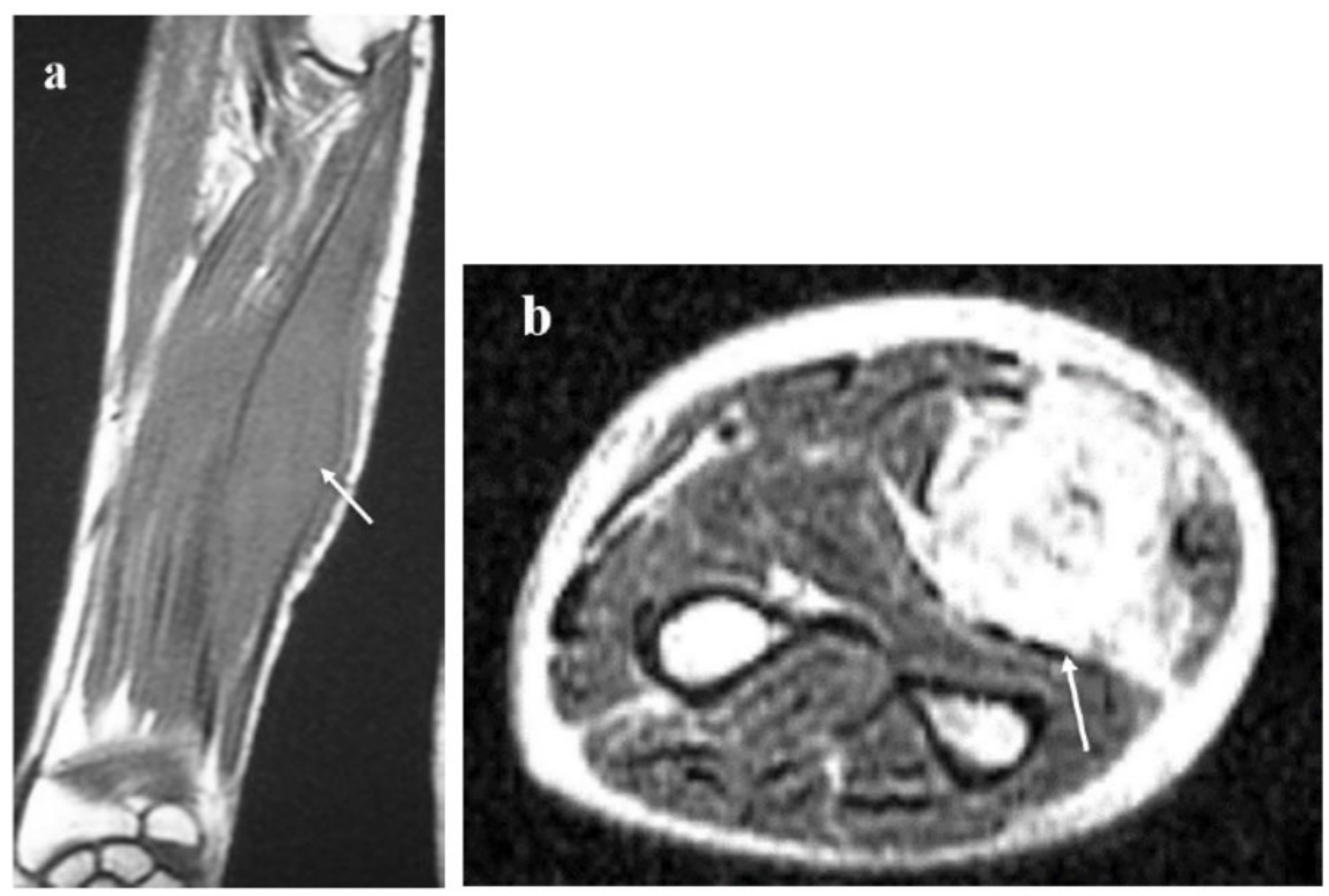

Figure 1. MRI from previous hospital. a. Coronal T1-weighted and b. Axial T2-weighted images. The lesion displays intermediate intensity on T1-weighted images (arrow) and high intensity on T2-weighted images (arrow).

Considering the possibility of malignant soft tissue tumors, such as a malignant peripheral nerve sheath tumor (MPNST), an incisional biopsy was performed. A malignant mesenchymal tumor, such as MPNST, as well as a malignant granular cell tumor were initially considered as a possibility upon examination of the frozen sections. The final pathology result was a malignant granular cell tumor, and tumor excision was planned. During surgery, there was a continuous tumor in the ulnar nerve. Marginal excision of the tumor was performed with a biopsy tract included in the excised tissue(see Figure 2).

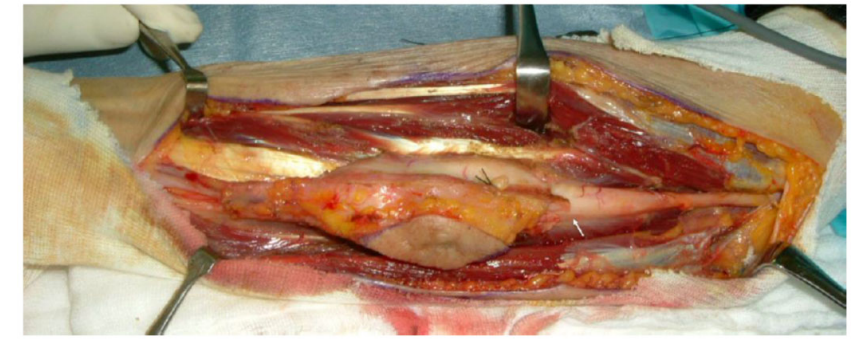

Figure 2. Intraoperative image during marginal excision. Note that the tumor is continuous with the ulnar nerve (arrow). 

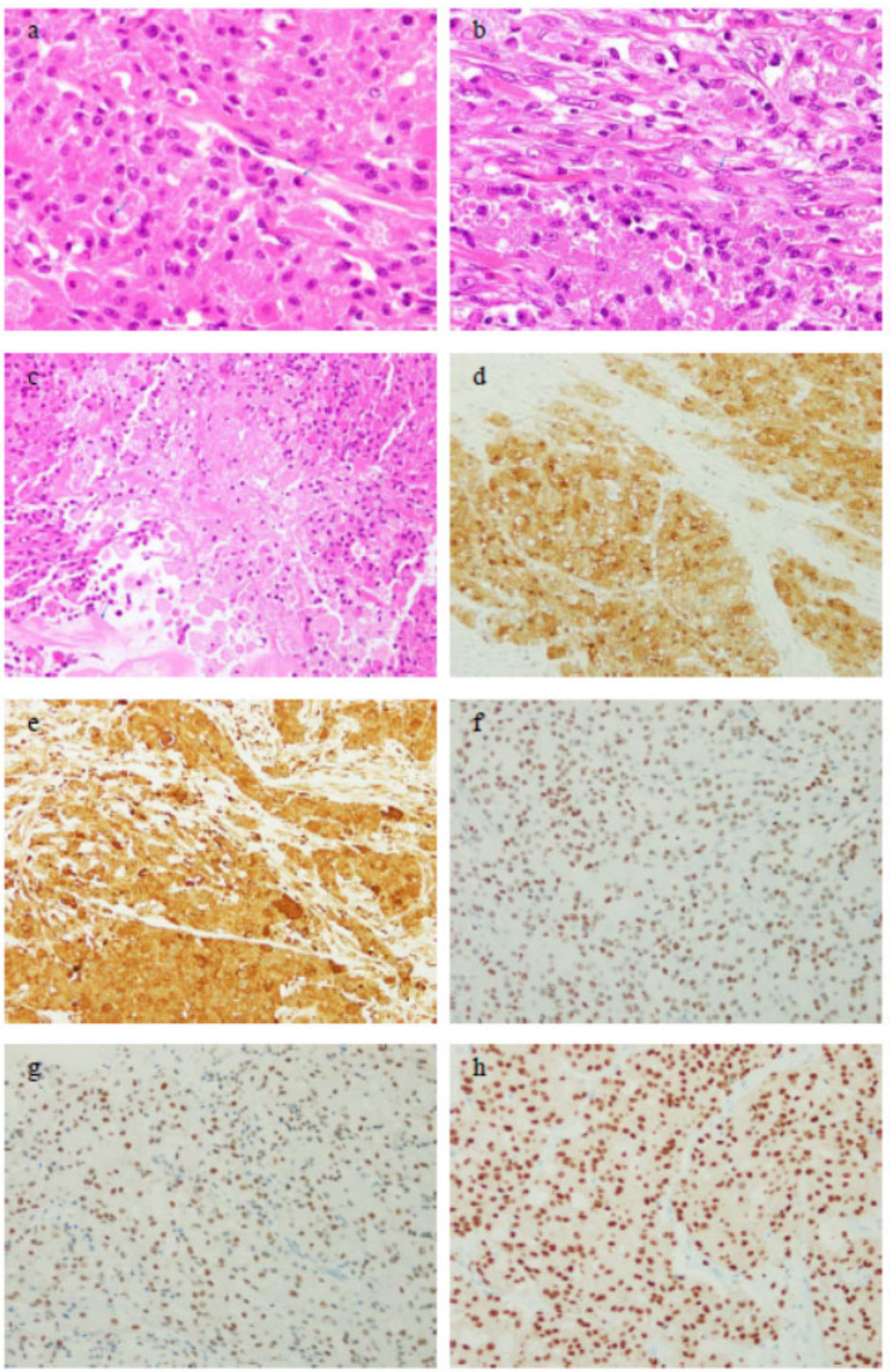

Figure 3. a: Hematoxylin and eosin staining (HE) showing mitosis; b: HE with spindling of the tumor cells; c: HE with necrosis; d: S-100; e: CD68; f: H3K27me3; g: TFE3; h: SOX10 
The tumor size was $9.2 \mathrm{~cm}$ in diameter and histologically consisted of eosinophilic, granular, polygonal to round, and spindle-shaped cells, with vesicular and large nucleoli, and increased mitosis (2-3/10 high-power fields) with a small necrosis area. Immunohistochemically, the tumor cells were positive for S-100 protein, CD68, H3K27me3, TFE3, and SOX10 and negative for smooth muscle alpha-actin, desmin, cytokeratin AE1/3, epithelial membrane antigen, and synaptophysin. The Ki-67 positivity rate was $12 \%$. These findings were consistent with those of malignant granular cell tumors. Clawing of the hand persisted after the surgery, but the patient was still able to farm. No recurrence or metastases were observed 15 years postoperatively (see Figure 3 ).

Table 1. Literature review of malignant granular cell tumor of the named peripheral nerve DOD, died of disease; NED, no evidence of disease; NA, not available; AWD, alive with disease

\begin{tabular}{|c|c|c|c|c|c|c|}
\hline Case & Age, sex & Nerve, location & Size (cm) & $\begin{array}{l}\text { Follow up } \\
\text { (months) }\end{array}$ & Outcome & References \\
\hline No.1 & 60 , female & Suboccipital nerve & 4 & 1 & NED & Meling et al. ${ }^{[4]}$ \\
\hline No.2 & 34 , male & Radial nerve in the upper arm & 10 & 19 & DOD & Usui et al. ${ }^{[6]}$ \\
\hline No.3 & 33 , female & Laryngeal nerve in the neck & 2 & 24 & NED & Weisman et al. ${ }^{[7]}$ \\
\hline No.4 & 43 , female & Sciatic nerve in the buttock & 9 & 13 & DOD & $\begin{array}{l}\text { Shimamura et al. } \\
{[8]}\end{array}$ \\
\hline No.5 & 51 , female & $\begin{array}{l}\text { Sciatic and tibial nerve in the } \\
\text { popliteal fossa }\end{array}$ & 12 & 12 & DOD & $\begin{array}{l}\text { Saperstein et al. } \\
{[9]}\end{array}$ \\
\hline No.6 & 30 , male & $\begin{array}{l}\text { Fifth cranial nerve in the } \\
\text { infratemporal fossa }\end{array}$ & 10 & 12 & AWD & Simsir et al. ${ }^{[10]}$ \\
\hline No.7 & $\begin{array}{l}54, \\
\text { male }\end{array}$ & Radial nerve in the forearm & 3 & 60 & AWD & Sonobe et al. ${ }^{[11]}$ \\
\hline No.8 & 64 , female & Tibial nerve in the leg & 2.5 & 16 & AWD & $\begin{array}{l}\text { Wieczorek et al. } \\
{[12]}\end{array}$ \\
\hline No.9 & 48 , female & Cervical sympathetic nerve trunk & 8.6 & 36 & NED & Hyodo et al. ${ }^{[13]}$ \\
\hline No.10 & 42 , male & Lateral femoral cutaneous nerve & 6 & 7 & AWD & $\begin{array}{l}\text { Tommaso et al. } \\
\text { [14] }\end{array}$ \\
\hline No.11 & 74 , male & Ulnar nerve in the forearm & 4.5 & NA & NA & $\begin{array}{l}\text { Papachristou et } \\
\text { al. }{ }^{[15]}\end{array}$ \\
\hline No.12 & 46 , female & Brachial plexus & 7.8 & 41 & NA & Go et al. ${ }^{[16]}$ \\
\hline No.13 & 64 , female & $\begin{array}{l}\text { Sympathetic nerve in the posterior } \\
\text { mediastinum }\end{array}$ & 15 & NA & NA & De Luca et al. ${ }^{[17]}$ \\
\hline No.14 & 14 , female & Radial nerve in the forearm & 1.5 & 10 & NED & Aviles et al. ${ }^{[18]}$ \\
\hline No. 15 & 51 , female & $\mathrm{C} 5$ root & 5 & 52 & DOD & Imao et al. ${ }^{[20]}$ \\
\hline No.16 & 67 , female & Median nerve in the palm & 5.2 & 6 & AWD & $\begin{array}{l}\text { Tsukamoto et al. } \\
\text { [21] }\end{array}$ \\
\hline No. 17 & 81 , male & Sciatic nerve in the thigh & 3.5 & NA & NA & Hurrell et al. ${ }^{[28]}$ \\
\hline No.18 & 71, female & Ulnar nerve in the forearm & 9.2 & 180 & NED & Current case \\
\hline
\end{tabular}

\section{Discussion}

To the best of our knowledge, 17 cases of malignant granular cell tumors arising from the peripheral nerve have been reported in the English literature (see Table 1). ${ }^{[4,6-18,20,21]}$ Only one case of an ulnar nerve-derived malignant granular cell tumors has been described. ${ }^{[16]}$ The diagnostic criteria of Fanburg et al. ${ }^{[3]}$ were used to distinguish between benign and malignant granular cell tumors: (1) necrosis, (2) spindling of the tumor cells, (3) vesicular nuclei with large nucleoli, (4) increased mitotic rate ( $>2$ mitoses/10 high-power fields), (5) a high nuclear-to-cytoplasmic ratio, and (6) polymorphism.
Tumors with three or more of these features were classified as malignant granular cell tumors. Tumors with only one or two features were classified as atypical, whereas tumors with none of these features or with only focal nuclear pleomorphism were considered benign. The specimens of this case were reviewed in 2020 by a pathologist from our institution using the World Health Organization classification and the diagnostic criteria by Fanburg-Smith et al. Items (2) through (4) were applicable for this case, and which met the histological diagnostic criteria for malignant granular cell tumors. Fanburg et al. ${ }^{[3]}$ reported a Ki-67 index $<5 \%$ in be- 
nign granular cell tumors, $5 \%-10 \%$ in atypical tumors, and $10 \%-50 \%$ in malignant granular cell tumors. Kapur et al. ${ }^{[22]}$ reported similar correlations and suggested that the Ki-67 index may be useful in distinguishing malignant or atypical granular cell tumors from benign ones. The Ki-67 index rate in this case was $12 \%$, which also indicated a malignant granular cell tumor. The differential diagnoses of malignant granular cell tumors include rhabdomyosarcoma, MPNST, and spindle cell carcinoma. Immunohistochemical staining is important for the diagnosis. Myogenic tumors show SMA positivity; MPNST shows weaker and focal expression of S100 and H3K27me3 in comparison to malignant granular cell tumors; and carcinomas more often express cytokeratins. Granular cell tumors express higher levels of TFE3. ${ }^{[23,24]}$ Patients with malignant granular cell tumors have a poor prognosis with a 5 -year survival rate of $60 \%-65 \%$, local recurrences in about $30 \%$, and distant metastases in about $50 \%{ }^{[3,25]}$ Metastasis at the first visit, local recurrence, and tumor size $>5 \mathrm{~cm}$ have been reported as poor prognostic factors. ${ }^{[3,26,27]}$ Moten et al. ${ }^{[27]}$ reported that undergoing surgery to excise malignant granular cell tumors was associated with a significantly better 5-year survival rate than not undergoing surgery $(81.9 \%$ vs. $30.7 \%$, respectively; $\mathrm{P}$ $<0.001)$. Chemotherapy has largely been used for locally recurrent disease or metastasis, and radiotherapy has also been used as both an adjuvant and palliative therapy. ${ }^{[25,26]}$ In contrast, our patient demonstrated a prolonged survival

\section{REFERENCES}

[1] Rose B, Tamvakopoulos GS, Yeung E, et al. Granular cell tumors: a rare entity in the musculoskeletal system. Sarcoma. 2009; 765927. https://doi.org/10.1155/2009/765927

[2] Ordóñez NG. Granular cell tumor: a review and update. Adv Anat Pathol. 1999; 6: 186-203. https://doi.org/10.1097/001254 80-199907000-00002

[3] Fanburg-Smith JC, Meis-Kindblom JM, Fante R, et al. Malignant granular cell tumor of soft tissue: diagnostic criteria and clinicopathologic correlation. Am J Surg Pathol. 1998; 22: 779-794. https://doi.org/10.1097/00000478-199807000-00001

[4] Meling TR, Fridrich K, Evensen JF. Nedregaard B: Malignant granular cell tumor of the skull base. Skull base. 2008; 18: 59-66. https://doi.org/10.1055/s-2007-992763

[5] Aksoy S, Abali H, Kilickap S, et al. Metastatic granular cell tumor: a case report and review of the literature. Acta Oncol. 2006; 45: 91-94. https://doi.org/10.1080/02841860500341132

[6] Usui M, Ishii S, Yamawaki S, et al. Malignant granular cell tumor of the radial nerve: an autopsy observation with electron microscopic and tissue culture studies. Cancer. 1977; 39: 1547-1555. https://doi.org/10.1002/1097-0142(1977 04) $39: 4<1547:$ :AID-CNCR2820390428>3 . 0 . C0 ; 2-0

[7] Weisman RA, Konrad HR, Canalis RF. Granular cell myoblastoma involving the recurrent laryngeal nerve. Arch Otolaryngol. 1980; without signs of a recurrence or metastatic disease, although the tumor size was significantly $>5 \mathrm{~cm}$ in diameter.

In summary, the authors report an interesting and rare case of 71-year-old woman presenting with a mass in her right forearm, which turned out to represent a malignant granular cell tumor originating from the ulnar nerve. After surgical removal of this mass, a detailed histological, as well as immunohistological examination was performed. In contrast to most of the published reports, the respective patient demonstrated a prolonged long-term survival without signs of a recurrence or metastatic disease, although the tumor size was large. Moreover, because of the rarity of malignant granular cell tumors, this case report adds interesting information to the field of this tumor entity.

\section{ACKNOWLEDGEMENTS}

Sei Morinaga, Norio Yamamoto, Katsuhiro Hayashi, Akihiko Takeuchi, Shinji Miwa, Kentaro Igarashi, Hirotaka Yonezawa, Yohei Asano, Shiro Saito, Takayuki Nojima, and Hiroyuki Tsuchiya determined treatment plan. Sei Morinaga and Norio Yamamoto conducted the follow-up. Sei Morinaga was a major contributor in writing the manuscript. Takayuki Nojima reviewed the histological specimens. Hiroyuki Tsuchiya oversaw the study. All authors read and approved the final manuscript.

\section{Conflicts of InTerest Disclosure}

The authors declare that they have no conflicts of interest.
106: 294-297.https://doi.org/10.1001/archotol.1980.00 790290046015

[8] Shimamura K, Osamura RY, Ueyama Y, et al. Malignant granular cell tumor of the right sciatic nerve. Report of an autopsy case with electron microscopic, immunohistochemical, and enzyme histochemical studies. Cancer. 1984; 53: 524-529. https://doi.org/10.1002/1097-0142(198402 01) $53: 3<524:$ : AID-CNCR2820530326>3.0.CO;2-5

[9] Saperstein AL, Lusskin R, Doniguian AE, et al. Malignant granular cell tumor mimicking herniated nucleus pulposus. Clin Orthop Relat Res. 1996; 324: 244-250. https://doi.org/10.1097/000030 86-199603000-00030

[10] Simsir A, Osborne BM, Greenebaum E. Malignant granular cell tumor: a case report and review of the recent literature. Hum Pathol. 1996; 27: 853-858. https://doi.org/10.1016/S004 6-8177 (96) 90462-1

[11] Sonobe H, Iwata J, Furihata M, e tal. Malignant granular cell tumor: report of a case and review of the literature. Pathol Res Pract. 1998; 194: 507-513. https://doi.org/10.1016/S0344-0338(98)8 0119-2

[12] Wieczorek TJ, Krane JF, Domanski HA, et al. Cytologic findings in granular cell tumors, with emphasis on the diagnosis of malignant granular cell tumor by fine-needle aspiration biopsy. Cancer. 2001; 93: 398-408. https://doi.org/10.1002/cncr.10143 
[13] Hyodo M, Sadamoto A, Murakami S. Malignant granular cell tumour of the cervical sympathetic nerve trunk. J Laryngol Otol. 2001; 115 : 833-835. https://doi.org/10.1258/0022215011909107

[14] Di Tommaso L, Magrini E, Consales A, et al. Malignant granular cell tumor of the lateral femoral cutaneous nerve: report of a case with cytogenetic analysis. Hum Pathol. 2002; 33: 1237-1240. https://doi.org/10.1053/hupa.2002.129207

[15] Papachristou DJ, Palekar A, Surti U, et al. Malignant granular cell tumor of the ulnar nerve with novel cytogenetic and molecular genetic findings. Cancer Genet Cytogenet. 2009; 191: 46-50. https : //doi.org/10.1016/j.cancergencyto.2009.01.011

[16] Go MH, Kim SH, Cho KH. Brachial plexus tumors in a consecutive series of twenty-one patients. J Korean Neurosurg Soc. 2012; 52: 138-143. https://doi.org/10.3340/jkns.2012.52.2.138

[17] De Luca G, Luciano A, Benincasa G, et al. Giant malignant granular cell tumor (GCT) of the posterior mediastinum. J Thorac Oncol. 2013; 8: 1107-1108. https://doi.org/10.1097/JT0.0b013e 318299ad62

[18] Aviles S, Tay T, Jones WD, et al. Intraneural malignant granular cell tumor-report of an extremely rare tumor in a child. Hand Surg. 2014; 19: 103-107. https://doi.org/10.1142/S02188104147 20046

[19] Hurrell MA, McLean C, Desmond P, et al. Malignant granular cell tumour of the sciatic nerve. Australas Radiol. 1995; 39: 86-89. https://doi.org/10.1111/j.1440-1673.1995.tb00242.x

[20] Imao K, Ogose A, Kawashima H, et al. Two cases treated with chemotherapy for malignant granular cell tumor. J East Jpn Orthop Traumatol. 2009; 21: 577-582.
[21] Tsukamoto S, Takeda M, Honoki K, et al. Malignant granular cell tumor of the median nerve: a case report with a literature review of 157 cases. Skeletal Radiol. 2019; 48: 307-316. https : //doi.org/10.1007/s00256-018-3017-2

[22] Kapur P, Rakheja D, Balani JP, et al. Phosphorylated histone H3, Ki$67, \mathrm{p} 21$, fatty acid synthase, and cleaved caspase- 3 expression in benign and atypical granular cell tumors. Arch. Pathol. Lab Med. 2007; 131: 57-64. https://doi.org/10.5858/2007-131-57-PHHKP $\mathrm{F}$

[23] Chamberlain BK, McClain CM, Gonzalez RS, et al. Alveolar soft part sarcoma and granular cell tumor: An immunohistochemical comparison study. Hum Pathol. 2014; 45: 1039-1044. https: //doi.org/10.1016/j.humpath.2013.12.021

[24] Schoolmeester JK, Lastra RR. Granular cell tumors overexpress TFE3 without corollary gene rearrangement. Hum Pathol. 2015; 46: 1242-1243. https://doi.org/10.1016/j.humpath.2015.04. 004

[25] Imanishi J, Yazawa Y, Saito T, et al: Atypical and malignant granular cell tumors in Japan: a Japanese musculoskeletal oncology group (JMOG) study. Int J Clin Oncol. 2016; 21: 808-816. https ://doi.org/10.1007/s10147-016-0949-1

[26] Moten AS, Movva S, von Mehren M, et al. Granular cell tumor experience at a comprehensive cancer center. J Surg Res. 2018; 226: 1-7. https ://doi.org/10.1016/j.jss.2018.01.027

[27] Moten AS, Zhao H, Wu H, et al. Malignant granular cell tumor: Clinical features and long-term survival. J Surg Oncol. 2018; 118 : 891-897. https://doi .org/10.1002/jso. 25227

[28] Hurrel MA, McLean C, Desmond P, et al. Malignant granular cell tumor of the sciatic nerve. Australas Radiol. 1995; 39: 86-89. https://doi.org/10.1111/j.1440-1673.1995.tb00242.x 